\title{
Promosi Mesjid Raya Pulau Penyengat sebagai Daerah Tujuan Wisata di Tanjung Pinang Kepulauan Riau
}

\author{
RIONO GEDE TRISOKO \\ J1. Pattimura No. 54 Gobah Pekanbaru - Riau \\ Telp. : 0761 - 35531 \\ Email: stipar_apeph@yahoo.com
}

\begin{abstract}
Various attempts to make the Masjid Raya Island Biting as an object of religious tourism in the province of Riau Islands, has been carried out by the manager and local governments, among others, promotion to tourists both domestic and international travelers is done so that the level of tourist arrivals which may come as expected. The development of tourist traffic that comes to Masjid Raya Island Biting the average level of tourists who come to the Masjid Raya Island stinger where traffic levels continue to decline. Descriptive method used and the results of data analysis known that the Department of Culture and Tourism in increasing the number of visits such as: the availability of tourism information center, stinger island festival, held in cooperation with travel agencies and increased advertising on the island stinger. And the presence of Culture and Tourism today can say is good. With various promotions conducted by the relevant authorities so that the future can increase traffic.
\end{abstract}

Keywords: Promotion, Tourism

Pariwisata dan budaya Indonesia dapat dijadikan sebagai suatu sumber industri pariwisata pendapatan negara dari sektor non migas. Hal ini didukung oleh potensi pariwisata alam, budaya dan peninggalan sejarah yang dimiliki Indonesia. Sebagai penghasil devisa negara, pariwisata melalui perbaikan dan penyempurnaan sarana dan prasarana objek wisata diharapkan mampu membuat kunjungan wisatawan terus meningkat. Indonesia merupakan negara yang kaya akan hasil alam yang dibarengi keindahan alam yang sangat menarik. Banyak orang dari negara luar datang ke Indonesia untuk menikmati keindahan alam yang dalam konteks kepariwisataan mereka datang sebagai wisatawan. Melihat kondisi ini pemerintah mencanangkan sektor pariwisata sebagai andalan kegiatan ekonomi setelah migas. Pengembangan sektor pariwisata dewasa ini terasa sangat penting karena berkaitan dengan penerimaan devisa negara dan menciptakan peluang terbukanya lapangan pekerjaan baru. Disamping itu juga untuk memperkenalkan alam dan kebudayaan Indonesia.

Salah satu faktor pendukung pertumbuhan pariwisata di Indonesia adalah dengan diimbangi oleh pengembangan dunia pariwisata. Keberadaan Pariwisata suatu daerah sangat mempengaruhi perkembangan kepariwisataan di daerah tersebut. Dalam menghadapi arus wisatawan, pihak pengelola terutama Dinas Pariwisata yang terkait perlu mempersiapkan diri sebaik mungkin, baik dari segi objek wisata, akomodasi, transportasi serta fasilitas yang mendukung. Provinsi Kepulauan Riau merupakan salah satu daerah tujuan wisata di Indonesia yang mempunyai objek-objek wisata yang cukup potensial untuk dikembangkan. Mulai diberlakukannya otonomi daerah oleh pemerintah pusat pada awal tahun 1998, membuat pemerintah provinsi Kepulauan Riau semakin gencar melakukan pembangunan di berbagai sektor, termasuk sektor pariwisata.

Propinsi Kepulauan Riau dengan Ibukota Tanjung Pinang Merupakan Provinsi yang cukup berkembang dengan pesatnya. Di Provinsi Kepulauan Riau pemerintahnya melakukan pengembangan-pengembangan kawasan pariwisata dengan cara menarik minat investor dan memberikan kemudahankemudahan bagi mereka melalui peraturanperaturan yang dikeluarkan oleh pemerintah 
setempat. Diharapkan dengan demikian kepariwisataan di Provinsi Kepulauan Riau dapat berkembang dengan baik.

Pariwisata merupakan salah satu alternatif dalam meningkatkan ekonomi di Provinsi Kepulauan Riau, karena dengan mengembangkan sektor ini diharapkan banyak wisatawan yang berkunjung ke Kepulauan Riau yang dengan sendirinya akan membawa devisa untuk dibelanjakan di negeri ini dengan mengupayakan pengembangan dan pemanfaatan potensi wisata yang dimiliki daerah dalam wujud kekayaan alam yang indah, keragaman flora dan fauna, kemajemukan tradisi dan seni budaya serta peninggalan sejarah dan purbakala. Melanjutkan prospek segitiga SIJORI yang cerah, pulau-pulau di Propinsi Kepulauan Riau terutama Pulau Batam, Pulau Rempang, dan Pulau Galang Tengah digarap untuk dihubungkan dengan jembatan menjadi satu kawasan BARELANG. Kawasan ini memperluas pengembangan Batam yang telah hampir mendekati Batas daya serap instansi di pulau tersebut.

Berbagai industri di Provinsi Kepulauan Riau seperti antara lain industri pengolahan hasil hutan dan industri hasil pertanian, yang meliputi minyak sawit, rotan, kayu lapis, crumb rubber, udang beku, ataupun industri dengan kadar ilmu pengetahuan dan teknologi tinggi, seperti industri pertambangan minyak dan gas bumi, industri perkapalan, industri mesin-mesin, dan manufaktur, berpotensi untuk dikembangkan. Pengembangan industri yang menggunakan teknologi madya dan tinggi tersebut dapat melibatkan serta memanfaatkan kehadiran perusahaan-perusahaan transnasional yang ada di provinsi ini.

Kepuluan Riau merupakan provinsi baru hasil pemekaran dari provinsi Riau. Provinsi Kepulauan Riau terbentuk berdasarkan Undang-undang Nomor 25 tahun 2002 merupakan provinsi ke-32 di Indonesia yang mencakup 2 kota dan 5 kabupaten yaitu: Kota Tanjung Pinang; Kota Batam; Kabupaten Bintan; Kabupaten Karimun; Kabupaten Natuna; Kabupaten Kepulauan
Anambas; dan Kabupaten Lingga. Keputusan Menteri Dalam Negeri Nomor : 130-67 Tahun 2002 tentang pengakuan kewenangan Kabupaten/Kota Provinsi menyangkut tentang kepariwisataan disebutkan bahwa masalah pengaturan dan pengelolaan objek dan daya tarik wisata serta penetapan inventarisasi potensi objek dan kawasan wisata merupakan kewenangan pemerintah daerah Kota/Kabupaten.

Selaras dengan keputusan ini maka semua kota melalui Dinas Pariwisata, Kebudayaan, Pemuda dan Olahraga melakukan investarisasi potensi objek wisata dan kawasan wisata yang ada di setiap kota dan kabupaten. Salah satu kota di Provinsi Kepulauan Riau yang sedang berkembang adalah kota Tanjung Pinang. Di kota Tanjung pinang terdapat berbagai macam objek wisata seperti wisata religi, wisata sejarah, wisata budaya, wisata kuliner, agro wisata dan sarana wisata. Hal ini membuat pemerintah provinsi Kepulauan Riau melalui dinas-dinas terkait dan investor bisnis pariwisata memikirkan alternatif lain di bidang pariwisata yaitu menjadikan Provinsi Kepulauan Riau sebagai kota bisnis wisata di pulau Sumatera. Guna mendukung semua itu pemerintah provinsi Kepulauan Riau bekerja sama dengan para investor membangun sarana-sarana yang mendukung kegiatan kepariwisataan tersebut, seperti perbaikan sarana prasarana dilokasi daerah tujuan wisata seperti hotel-hotel berbintang bertaraf internasional serta bermacam - macam pusat pembelanjaan.

Dimana dalam konteks wilayah kota Tanjung Pinang memiliki sebuah pulau yaitu Pulau Penyengat. Pulau Penyengat ini terletak di sebelah barat kota Tanjung Pinang. Secara astronomi Pulau Penyengat terletak pada $\mathrm{O}^{0} 56^{\prime} \mathrm{LU}$ dan $104^{\circ} 29^{\prime} \mathrm{BT}$ dengan panjang $2 \mathrm{~km}$, lebar $1 \mathrm{~km}$. Pulau Penyengat ini sering disebut dengan istilah Pulau Maskawin karena pulau ini merupakan Maskawin Sultan Mahmudsyah untuk Engku Puteri Raja Hamidah. Pulau Penyengat dikenal dengan nama Pulau Penyengat Indra Sakti. 
Dari sekian banyak objek wisata di kota Tanjung Pinang, yang paling memliki nilai sejarah dan keunikan tersendiri adalah Mesjid Raya Pulau Penyengat, untuk mengunjungi objek wisata Masjid Raya Pulau Penyengat, hanya memerlukan waktu sekitar 30 menit dari pusat kota dengan menggunakan kendaraan umum, atau kendaraan pribadi dan dilanjutkan dengan perahu motor kecil (kapal pompong) karena objek tersebut ada di seberang Pulau Tanjung Pinang, objek wisata ini biasanya ramai dikunjungi pada saat akhir pekan atau hari libur. Wisatawan yang datang pun beragam, baik yang dari dalam provinsi Kepulauan Riau sendiri maupun dari luar provinsi Kepulauan Riau. Dalam hal jumlah pengunjung, dapat dikatakan setiap hari pasti ada pengunjung tetapi tidak seperti yang diharapkan oleh pihak pengelola maupun dari pihak pemerintah selaku pembina sarana dan prasarana kepariwisataan namun untuk beribadah sholat tetap berjalan seperti biasanya.

Berbagai upaya untuk menjadikan Masjid Raya Pulau Penyengat sebagai objek wisata religi di provinsi Kepulauan Riau, telah dilakukan oleh pihak pengelola dan pemerintah daerah antara lain melakukan promosi baik kepada wisatawan domestik maupun wisatawan internasional ini dilakukan agar tingkat kunjungan wisatawan yang datang dapat seperti yang diharapkan. Adapun perkembangan tingkat kunjungan wisatawan yang datang ke Masjid Raya Pulau Penyengat rata-rata tingkat kunjungan wisatawan yang datang ke Mesjid Raya Pulau penyengat yang mana tingkat kunjungan terus mengalami penurunan. Hal ini dikarenakan kurangnya promosi serta kurangnya fasilitas sarana dan prasarana yang dibangun di kawasan Mesjid raya tersebut. Dalam hal ini sangat dituntut upaya dari pemerintah setempat khususnya Dinas Kebudayaan dan Pariwisata untuk meningkatkan lagi kunjungan wisatawan. Berbagai upaya untuk menjadikan Masjid Raya Pulau Penyengat sebagai objek wisata unggulan di Provinsi Kepulauan Riau, telah dilakukan oleh pihak pengelola antara lain melakukan promosi baik kepada wisatawan domestik maupun wisatawan internasional. Bermacam promosi yang dilakukan adalah dengan mengadakan iklan di media cetak dan media elektronik.

Berdasarkan uraian yang dikemukakan di atas, maka penulis tertarik untuk menjadikan Masjid Raya Pulau Penyengat sebagai tempat penelitian dengan pertimbangan sebagai berikut : Masjid Raya Pulau Penyengat memiliki potensi untuk dijadikan sebagai objek wisata religi yang siap dikunjungi. Adanya kawasan pendukung di sekitar mesjid yang dapat dikunjungi oleh wisatawan namun belum tertata dengan baik. Masjid Raya Pulau Penyengat mudah terjangkau untuk dikunjungi baik dari provinsi Kepulauan Riau maupun luar daerah provinsi Kepulauan Riau. Mesjid Raya Pulau Penyengat merupakan bukti sejarah agama Islam masuk ke provinsi Kepulauan Riau.

Sebagai kerangka pemikiran di dalam penulisan perlu adanya landasan-landasan teori yang mendukung penelitian ini. Sesuai dengan uraian yang lainnya, berikut ini penulis akan mengemukakan beberapa teori yang ada hubungannya dengan masalah yang dibahas. Menurut Himawan Kartajaya, (2009: 10) strategi adalah konsep pemasaran diantaranya mencakup positioning, segmentasi dan targeting. Strategi dalam pariwisata mencakup yang ditawarkan oleh DTW (Daerah Tujuan Wisata) kepada wisatawan yang real maupun yang potensial. Penawaran dalam pariwisata menunjukkan khasanah atraksi wisata alamiah dan buatan manusia, jasa-jasa maupun barang-barang yang kira-kira akan menarik orang-orang untuk mengunjungi suatu Negara tertentu. Menurut Oka A. Yoeti, (2006:237) yang mengutip pendapat Kotler yang memperkenalkan bauran pemasaran dalam strategi untuk meningkatkan penjualan paket wisata melalui empat-P, yaitu product, price, place dan promotion.

Promosi adalah suatu upaya yang dilakukan untuk menyesuaikan produk pariwisata dengan permintaan wisatawan 
sehingga produk menjadi lebih menarik. (Happy Marpaung, 2002:103).

Menurut Philip Kotler (2000: 265) mendefinisikan Marketing sebagai suatu proses sosial dan manajerial dan melalui proses tersebut individu dan kelompok memperoleh apa yang mereka butuhkan serta inginkan lewat penciptaan dan pertukaran timbal balik produk-produk dan nilai dengan orang lain. Sementara menurut masyarakat umum pemasaran hanya merupakan penjualan dan periklanan seperti melalui surat kabar, televisi, selebaran, dan lain sebagainya.

Promosi merupakan salah satu variabel yang dipakai untuk mempengaruhi pasar bagi suatu produk maupun jasa dari suatu perusahaan. Banyak yang berpendapat bahwa promosi itu sama dengan penjualan, Kegiatan promosi dalam prakteknya menurut Basu Swastha (1995 : 278) adalah sebagai alat untuk : Modifikasi tingkah laku, Orangorang yang melakukan komunikasi itu mempunyai beberapa alasan, antara lain mencari kesenangan, mencari bantuan, memberi pertolongan atau instruksi, pengembangan ide dan pendapat. Sedangkan promosi dari segi lain berusaha merubah sikap tingkah laku dan pendapat, serta memperkuat sikap dan tingkah laku yang telah ada. Penjual sebagai sumber selalu berusaha menciptakan kesan yang baik yang ada pada dirinya (lembaganya) untuk mendorong peningkatan pembelian barang dan jasa yang ditawarkan. Pemberitahuan, kegiatan promosi dapat ditujukan untuk memberitahu pasar yang dituju tentang penawaran hasil produk suatu perusahaan. Promosi yang bersifat informasi ini harus dilakukan sejak tahap-tahap awal dari siklus kehidupan produk. Sebagian konsumen tidak akan membeli suatu produk, apabila mereka belum mengetahui apa bentuk produk tadi dan apa faedahnya produk tadi. Promosi yang bersifat informative ini sangat penting dilaksanakan, karena akan sangat terkesan membantu untuk membeli atau tidak membeli. Membujuk, Promosi yang bersifat membujuk (persuasif) umumnya kurang disenangi oleh sebagian masyarakat. Namun kenyataannya dewasa ini promosi yang bersifat persuasif ini malah tumbuh dan berkembang, karena hasinya sangat menguntungkan. Promosi ini terutama ditujukan untuk menigkatkan jumlah pembelian dari suatu produk yang telah mulai memasuki tahap pertumbuhan dalam siklus kehidupannya. Mengingatkan, promosi yang bersifat mengingatkan dilakukan terutama untuk mempertahankan merk suatu produk agar tetap diminati oleh para konsumen. Promosi macam ini sangat perlu dilakukan apabila produk tadi telah memasuki tahap kedewasaan dalam siklus kehidupannya.

Menurut Salah Wahab ( $1992: 158$ ) Tujuan publikasi dan promosi adalah: publikasi terutama berkaitan dengan calon pembeli yang masih belum dikenal. Promosi terutama diarahkan pada calon pembeli yang sudah dikenal atau diketahui secara pribadi. Pada setiap bidang tugas ini ada 3 tujuan yang harus di cakup : Memperkenalkan produk wisata seluas mungkin. Menyusun produk itu agar sedapat mungkin menarik. Dengan demikian mendorong sebanyak mungkin orang, yang sudah mengenal produk wisata itu, untuk mencobanya. Menyampaikan isi pesan yang menarik , tanpa harus berbohong.

Oka A. Yoeti (2006:292)

menyebutkan bahwa tujuan sales promotion yang penting adalah: Memperkenalkan produk baru; Meningkatkan frekuensi pemakaian; Menembah persediaan agen sebagai distributor; Menarik pelanggan baru; Counter terhadap aktivitas promosi yang dilakukan para pesaing; Mengaktifkan penjualan diwaktu sepi; dan Membantu kelancaran tugas sales executive melakukan pendekatan kepada pelanggan. Menurut Basu Swastha (2002: 214) pemasaran adalah suatu system keseluruhan dari kegiatan usaha yang dirancang untuk merencanakan, menetapkan harga, mempromosikan dan mendistribusikan barang, jasa dan ide-ide yang dapat memuaskan keinginan pasar sasaran dalam usaha mencapai tujuan organisasi. 
Dan menurut Philip Kotler (2000:378) pengertian bauran pemasaran (Marketing Mix) adalah kombinasi dari empat variabel atau kegiatan yang merupakan inti dari system pemasaran yakni produk, struktur harga, system distribusi dan kegiatan promosi. Keempat unsur yang terdapat dalam kombinasi tersebut saling berhubungan dan saling mempengaruhi. Setiap variabel yang ada masing-masing mempunyai banyak sekali sub variabel, dengan demikian manajer harus dapat memilih kombinasi terbaik sehingga didapat ramuan yang sesuai dengan kondisi lingkungan. Kotler secara ringkas menguraikan masing-masing variabel marketing mix sebagai berikut : Product (Produk): barang dan atau jasa yang ditawarkan di pasar untuk dikonsumsi oleh konsumen. Pengolahan produk termasuk di dalamnya perencanaan dan pengembangan produk dan atau jasa yang baik untuk dapat dipasarkan oleh perusahaan. Beberapa elemen dari produk tadi antara lain ialah kualitas, bentuk fisik, kemasan, merk dagang, servis, dan lain-lain. Price (harga): harga menduduki tempat yang penting karena akan menentukan penerimaan perusahaan. Dalam menentukan harus menitikberatkan pada kemampuan pembeli pada harga yang telah ditetapkan. Harga bukan semata-mata untuk menutupi biaya produk dan keuntungan yang diinginkan perusahaan, tetapi yang lebih penting akan menunjukkan persepsi konsumen terhadap suatu produk. Place (distribusi); merupakan upaya agar produk yang ditawarkan berada pada tempat dan waktu yang tepat sesuai dengan kebutuhan konsumen dengan biaya wajar.

Objek wisata merupakan dasar bagi kepariwisataan. Tanpa adanya daya tarik di suatu daerah tertentu maka kepariwisataan sulit untuk dikembangkan. Pariwisata biasanya akan dapat lebih berkembag atau dikembangkan jika disuatu daerah terdapat lebih dari satu objek wisata. Menurut Salah Wahab (1992:28), pemasaran wisata adalah proses manajemen dimana organisasi pariwisata nasional dan/atau badan-badan usaha wisata dapat mengidentifikasi wisata pilihannya baik yang aktual maupun potensial, dapat berkomuniukasi dengan mereka untuk meyakinkan dan mempengaruhi kehendak, kebutuhan, motivasi, kesukaan dan hal yang tidak disukai, serta merumuskan dan menyesuaikan produk wisata mereka secara tepat, dengan maksud mencapai kepuasan optimal wisatawan sehingga dengan begitu mereka dapat meraih saran-sarannya.

Konsep pemasaran merupakan filsafat syarat bisnis yang mengatakan bahwa pemuasan kebutuhan konsumen merupakan syarat ekonomi dan sosial bagi kelangsungan hidup organisasi. Penggunaan konsep pemasaran yang jitu dapat ilut menunjang berhasilnya pelayanan yang diberikan kepada konsumen, (Stanton, 1996:98). Manajemen pemasaran adalah sebagai kegiatan yang direncanakan, dan diorganisasiknan yang meliputi pendistribusian barang, penetapan harga dan dilakukan pengawasan terhadap kebijakan-kebijakan yang telah dibuat yang tujuannya untuk mendapatkan tempat dipasar agar tujuan utama dari pemasaran dapat tercapai.

Konsep pemasaran yang telah diungkapkan dengan berbagai cara: Temukan keinginan pasar dan penuhilah. Buatlah apa yang dapat dijual dan jangan berusaha menjual apa yang dapat dibuat. Cintailah pelanggan, bukan produk anda. Lakukanlah menurut cara anda. Andalah yang menentukan. Melakukan segalanya dalam batas kemampuan untuk menghargai uang pelanggan yang sarat dengan nilai, mutu dan kepuasan. Promosi menurut R. S. Damardjati (2001:12) yang mempunyai Badan Promosi Pariwisata Indonesia (BPPI) adalah organisasi non pemerintah yang bertujuan untuk meningkatkan promosi pariwisata Indonesia di luar negeri. Para petugas BPPI ini rata-rata terdiri penguasa/pengusaha swasta yang bergerak dibidang pariwisata ataupun produk-produk jasa lain yang secara langsung maupun tidak langsung. Banyak pengertian tentang promosi yang dikemukakan oleh para ahli keanekaragaman tentang rumusan promosi tersebut antara lain, 
menurut Philip Kotler (2001:74) yang mendefenisikan promosi sebagai kreatifitas mengkomunikasikan keunggulan produk serta membujuk pelanggan sasaran untuk membelinya.

\section{METODE}

Metode penelitian deskriptif digunakan dalam penelitian ini. Yang menjadi populasi dalam penelitian ini melibatkan Kepala Dinas, staff yang ada di Dinas Kebudayaan dan Pariwisata khususnya Divisi Pengembangan Kepariwisataan, pengurus Mesjid Raya dan wisatawan yang datang ke kawasan Mesjid Raya Pulau Penyengat. Data yang diperoleh dari hasil observasi dan wawancara dipilah-pilah dan diklasifikasikan menurut jenisnya dan kemudian dianalisis serta diolah dengan menggunakan metode tabulasi terhadap data yang terkumpul, kemudian melakukan analisis untuk mendapatkan gambaran dan disimpulkan secara nyata yang sesuai dengan tujuan penelitian ini.

\section{HASIL}

Sektor pariwisata pada saat ini merupakan sumber penerimaan negara yang paling diandalkan setelah penerimaan negara dari sektor minyak bumi dan gas alam merosot. Sehubungan dengan hal ini upaya peningkatan pembangunan sektor pariwisata sangat diperlukan. Sebagaimana yang tercantum dalam GBHN dinyatakan mengembangkan dan mendayagunakan sumber dan potensi kepariwisataan nasional menjadi kegiatan yang diandalkan untuk memperbesar penerimaan devisa, memperluas dan memeratakan kesempatan berusaha dan lapangan kerja terutama bagi masyarakat setempat, mendorong pembangunan daerah dan memperkenalkan alam budaya bangsa.

Promosi daerah tujuan wisata merupakan salah satu faktor yang sangat menentukan dan menjadi bagian penting bagi pengembangan pariwisata suatu kota. Promosi wisata di Kota Tanjung Pinang khususnya Pulau Penyengat sangat gencar dilakukan oleh Dinas Kebudayaan dan
Pariwisata Kota Tanjung Pinang. Mengingat dunia pariwisata merupakan produk unggulan dan penyumbang terbanyak dari pendapatan asli daerah (PAD) Kota Tanjung Pinang, maka kegiatan promosi pariwisata Kota Tanjung Pinang masuk dalam agenda kerja dari Pemerintah Kota Tanjung Pinang. Selain dari Pemerintah Kota Tanjung Pinang, kegiatan promosi wisata juga dilakukan para pengelola usaha pariwisata seperti: hotel, restoran dan pengelola objek wisata.

Mesjid Raya Pulau Penyengat merupakan salah satu andalan dalam mendukung wisata religi, sejarah dan budaya di Provinsi Kepulauan Riau mengingat banyaknya peninggalan situs-situs di pulau ini yang bisa menjadi objek unggulan bagi wisatawan domestik dan wisatawan internasional. Maka ada beberapa upaya yang dilakukan oleh Dinas Kebudayaan dan Pariwisata Tanjung Pinang dalam mempromosikan Pulau Penyengat yaitu:

1. Disediakannya Pusat Informasi Pariwisata. Sejauh ini kegiatan promosi wisata yang dilakukan di Kota Tanjung Pinang baru terbatas pada penyediaan informasi berupa brosur, stiker dan pamflet yang disebarluaskan di lokasi masingmasing objek wisata. Pelaksanaan promosi wisata seperti ini tentu saja belum efektif karena terbatas pada masing-masing objek wisata dan belum menggambarkan potensi wisata secara keseluruhan. Pusat promosi wisata di Kota Tanjung Pinang yang dikelola oleh Pemerintah Kota Tanjung Pinang yang bernama Pusat Informasi Pariwisata yang lokasinya terletak di Jalan Merdeka serta berdampingan dengan Kantor Dinas Kebudayaan dan Pariwisata Kota Tanjung Pinang. Hal ini menunjukkan bahwa masih ada kesempatan bagi Dinas Kebudayaan dan Pariwisata kota Tanjung Pinang untuk meningkatkan promosi pariwisata Pulau Penyengat tidak hanya sebatas brosur, stiker dan 
pamflet yang di sebar dilokasi objek wisata dan di tempatkan di pusat informasi pariwisata. Dengan tersedianya pusat informasi yang baik diharapkan wisatawan dapat lebih mengetahui dengan cepat dan akurat mengenai kawasan objek wisata di Tanjung Pinang khususnya Pulau Penyengat.

2. Diadakannya Festival Pulau Penyengat. Festival yang digagas Kementerian Pariwisata dan Ekonomi Kreatif ini bisa menjadi momentum untuk mempromosikan Penyengat sebagai pusat kebudayaan dan bahasa Melayu di Indonesia. Acara Festival Pulau Penyengat ini di selenggarakan setiap akhir tahun. Salah satu alasan menyelenggarakan Festival Pulau Penyengat ini adalah karena keunikan pulau tersebut atas berbagai peninggalan sejarah peradaban Melayu pada masa kerajaan Riau Lingga. Kementerian menargetkan pada 2012, festival ini diselenggarakan lebih besar lagi dengan melibatkan peserta dari negara tetangga seperti Singapura dan Malaysia yang juga memiliki sejarah Melayu. Kegiatannya pun dibuat lebih banyak sehingga turis dari daerah lain bisa turut hadir menyemarakkan suasana. Untuk mendukung rencana tersebut, pemerintah provinsi Kepulauan Riau telah mengagendakan serangkaian pembangunan infrastruktur pendukung di Penyengat seperti penyediaan listrik, air bersih dan jalan akses menuju situs sejarah. Perumahan di pinggir laut akan direhabilitasi agar terlihat lebih semarak dari kejauhan. Dan akan membuat Penyengat lebih terang benderang pada malam hari. Pemerinta provinsi juga akan merehabilitasi beberapa situs yang sudah rusak agar semakin menarik para pelancong yang berkunjung ke pulau tersebut. Rasanya tidak berlebihan jika perintah provinsi Kepulauan Riau berharap Penyengat bisa menyedot wisatawan yang ingin menyaksikan bukti sejarah kebesaran kerajaan Melayu di Kepulauan Riau. Festival Pulau Penyengat sangat baik untuk dilaksanakan apabila didukung semua pihak terkait baik Dinas Kebudayaan dan Pariwisata kota Tanjung Pinang dan masyarakat pulau penyengat sendiri. Karena dengn kerjasama yang baik tersebut festival Pulau Penyengat akan menjadi sarana promosi secara langsung kepada wisatawan dalam dan luar negeri yang berkunjung pada saat festival tersebut diadakannya festival ini maka akan banyak orang yang mengetahui tentang kota Tanjung Pinang khususnya pulau Penyengat sehingga akan banyak mendatangkan wisatawan nusantara dan wisatawan mancanegara.

3. Diadakannya Kerjasama dengan Travel Biro. Dapat diketahui bahwa travel biro memiliki peran yang strategis dalam mengembangan pariwisata kota Tanjung Pinang khususnya Pulau Penyengat. Dalam rangka pembangunan kota Tanjung Pinang di sektor pariwisata diperlukan keterlibatan biro perjalanan untuk menentukan pasar wisata yang tepat agar dapat dicapai hasil yang optimal. Dengan melihat peran travel biro yang dominan dalam menyampaikan informasi wisata di kota Tanjung Pinang, dan telah dapat dilihat keberhasilannya, maka pemerintah hendaknya lebih meningkatkan kerjasamanya kepada travel biro. Bentuk kerjasama yang dapat dilakukan dapat berbentuk penyusunan kalender even dan penciptaan daya tarik wisata yang lebih bersifat dinamis sesuai dengan perkembangan minat pasar. Dalam hal ini biro perjalanan lebih memiliki pengalaman lapangan dan bentuk 
288 Promosi Mesjid Raya Pulau Penyengat sebagai Daerah Tujuan Wisata di Tanjung Pinang Kepulauan Riau (Riono Gede Trisoko)

kerjasama praktis dengan travel biro di berbagai daerah. Manfaat yang diperoleh antara lain: Pemerintah dapat lebih menghemat biaya promosi, namun target yang dicapai akan lebih tepat (manfaat efesiensi dan efektivitas). Penyampaian citra pariwisata bersifat positif. Feed back informasi dari biro perjalanan kepada pemerintah lebih bersifat up-date terkait dengan perkembangan minat wisatawan. staff Dinas Kebudayaan dan Pariwisata menjawab Baik yaitu 3 orang $50 \%$. Kerjasama dengan travel biro sebenrnya memberikan umpan balik yang sangat bagus bagi perkembngan pariwisata di Pulau Penyengat. Travel biro dapat menawarkan paket-paket perjalanan wisata ke Pulau Penyengat kepada para wisatawan sebagai objek wisata religi, sejarah dan budaya. Dengan kerjasama ini tentu akan lebih mendatangkan wisatawan ke Pulau Penyengat karena bagaimanapun travel biro akan lebih pro aktif membawa wisatawan datang.

4. Memperbanyak Iklan tentang Pulau Penyengat. Komponen lainnya di bidang promosi wisata ini adalah memperbanyak brosur atau mengiklankan di media massa tentang tempat dan objek wisata yang menarik dikunjungi di kota Tanjung Pinang khususnya di Pulau Penyengat. Hal ini dilakukan sebagai upaya untuk lebih memperkenalkan tempat dan objek wisata yang layak dikunjungi oleh wisatawan yang datang ke kota ini. Dengan adanya kegiatan promosi wisata melalui brosur dan iklan di media massa maka peningkatan kegiatan promosi wisata akan lebih efisien dan efektif karena mudah didapatkan dan didengar oleh wisatawan sehingga menimbulkan keinginan untuk datang berkunjung ke kota Tanjung Pinang khususnya Pulau Penyengat. Upaya lainnya dari kegiatan promosi ini adalah memperbanyak baleho atau papan iklan di pusat kota dan tempat-tempat tertentu yang ramai dikunjungi. Pemasangan baleho ini merupakan salah satu faktor yang relevan dalam memperkenalkan tempat dan objek wisata sehingga lebih dikenal oleh wisatawan. Staff Dinas Kebudayaan dan Pariwisata dalam mempromosikan iklan pariwisata Pulau Penyengat menyatakan sangat baik dengan persentase $16,7 \%$, dan yang menyatakan baik sebesar 33,3\%. Sedangkan yang menyatakan cukup baik sebesar $50 \%$ atau 3 orang. Pemasangan iklan di media massa dan media elektronik, baleho dan papan iklan dipusat kota dan tempattempat keramaian serta di objek wisata lainnya dapat dilakukan sebagai alat promosi untuk menarik wisatawan agar berkunjung ke Pulau Penyengat. Seiring dengan perkembangan teknologi saat ini tidak ada salahnya jika Dinas Kebudayaan dan Pariwisata membuat iklan di media-media social dan di website Dinas secara lebih gencar. Semua ini dilakukan dengan harapan meningkatkan kunjungan wisatawan ke Pulau Penyengat melalui beberapa usaha tersebut dapat di atas diharapkan pengembangan pariwisata yang dilakukan akan lebih mampu menahan wisatawan lebih lama berada di kota Tanjung Pinang khusnya Pulau Penyengat. Sehingga akan semakin dapat meningkatkan Pendapatan Asli Daerah (PAD) kota Tanjung Pinang. Selain peningkatan Pendapatan Asli Daerah (PAD), diharapkan juga sebagai penggerak roda perekonomian perdagangan, hiburan, restoran, tranportasi dan lain-lain di Pulau Penyengatsecara khusus dan kota Tanjung Pinang secara umum. 


\section{Persepsi Wisatawan Terhadap Objek Wisata Mesjid Raya Pulau Penyengat Sebagai Objek Wisata oleh Dinas Kebudayaan dan Pariwisata di Tanjung Pinang}

Motivasi kunjungan wisatawan baik lokal maupun wisatawan mancanegara ke Pulau Penyengat, khususnya Singapura dan Malaysia erat kaitannya dengan keberadaan objek-objek wisata sejarah dan sosial budaya yang terdapat di kota ini. Dengan demikian motif kunjungan mereka termasuk ke dalam kategori menikmati dan mengagumi kekayaan sejarah dan budaya di Pulau Penyengat. Disisi lain, banyak juga wisatawan tersebut yang datang karena adanya hubungan kekerabatan (etnis Melayu) dengan sanak saudara yang ada di Pulau Penyengat. Berikut ini penulis sajikan tanggapan wisatawan yang datang ke Pulau Penyengat berdasarkan:

\section{Tanggapan Terhadap Atraksi Wisata}

Kebutuhan atraksi wisata yang berbasis pada budaya Melayu lebih banyak diinginkan karena hal ini akan mendekatkan budaya masyarakat Melayu di Pulau Penyengat dengan masyarakat Melayu di Malaysia. Kondisi ini menunjukkan bahwa kebiasaan melihat budaya masyarakat Pulau Penyengat mempunyai daya tarik tersendiri dengan penampilan budaya masyarakat Melayu di Malaysia. Karena perbedaan geografis dan regional menyebabkan budaya Melayu di Pulau Penyengat (Kepulauan Riau) menjadi berbeda dengan budaya Melayu di Malaysia. Ketertarikan wisatawan Malaysia terhadap atraksi budaya dikarenakan faktor keingintahuan mereka terhadap karakteristik budaya masyarakat Melayu di Pulau Penyengat (bangsa serumpun) sehingga menimbulkan nuansa untuk dapat melihat suasana kampung halaman pada masa lalu (Kerajaan Johor Pahang Riau Lingga).

Beberapa atraksi wisata di kawasan Mesjid Raya Pulau Penyengat seperti : Pertunjukan pembacaan syair gurindam 12; Perlombaan seni tari tradisional oleh sanggar tari yang ada di Provinsi Kepulauan Riau; dan
Perlombaan takbir di Mesjid Raya Pulau Penyengat pada bulan Ramadhan. Rata-rata wisatawan menilai bahwa atraksi wisata yang ditampilkan tergolong ke dalam hal Baik yaitu 9 orang 30\% tetapi masih ada yang menilai bahwa atraksi wisata tergolong ke dalam hal Tidak Baik yaitu 6 orang $20 \%$. Adapun alasan para wisatawan tersebut menilai hal demikian adalah: Kondisi atraksi wisata yang ada di Pulau Penyengat belum mampu menarik minat wisatawan untuk melihatnya. Permintaan pasar terbanyak terhadap atraksi wisata adalah adat istiadat dikarenakan sangat kentalnya budaya wisatawan dari Malaysia dengan budaya masyarakat Melayu di Pulau Penyengat. Sangat dirasakan oleh wisatawan bahwa minim sekali di Pulau Penyengat pertunjukkan kesenian tradisional (Melayu). Atraksi yang paling disukai wisatawan adalah bangunan bersejarah, maka diperlukan pengelolaan bangunan-bangunann bersejarah yang ada di Pulau Penyengat, sekaligus dalam rangka melestarikan peninggalan budaya di Pulau Penyengat.

\section{Terhadap Pengelolaan Wisata}

Berkembang atau semakin banyaknya wisatawan yang mendatangi suatu dearah tujuan wisata sangat tergantung pada pemerintah daerah setempat atau pihak swasta mengola tempat dan objek wisata yang ada di daerah tersebut. Permintaan terhadap peningkatan sistem pengelolaan tempat dan objek wisata diarahkan pada penyediaan fasilitas dan tenaga yang terampil (sumber daya manusia). Peningkatan fasilitas wisata merupakan potensi atau modal wisata yang kuat sehingga pengembangan tempat dan objek wisata makin ramai dikunjungi. Rata-rata menjawab cukup baik yaitu 15 orang $50 \%$. Namun masih adanya wisatawan yang menjawab Tidak Baik yaitu 5 orang $16,7 \%$ dikarenakan beberapa alasan sebagai berikut ini: Sangat dirasakan bahwa fasilitas wisata yang ada di Pulau Penyengat kurang memadai dan pada akhirnya mengurangi motivasi wisatawan untuk datang berkunjung. Kurangnya fasilitas yang 
memadai, ruangan dan gedung, serta belum tersedianya pusat perbelanjaan dan hiburan yang berskala Internasional. Menyediakan dan mengembangkan berbagai sarana penunjang pariwisata yang dapat memberikan kenyamanan kepada wisatawan yang berkunjung ke berbagai obyek dan daya tarik wisata di Pulau Penyengat.

Dalam kerangka pengelolaan obyek dan daya tarik wisata Pulau Penyengat, diperlukan beberapa usaha ekstra untuk menjaga agar aset budaya dan pariwisata tersebut tetap lestari meskipun pemanfaantannya lebih berorientasi ekonomis. Usaha pengelolaan tersebut antara lain: Revitalisasi kawasan pariwisata dan obyek-obyek wisata budaya dan sejarah, terutama Pulau Penyengat. Mengembangkan dan meningkatkan jenis produk pariwisata budaya dan sejarah yang memiliki keunggulan kompetitif sesuai dengan kondisi Pulau Penyengat sehingga lebih menarik lagi bagi para wisatawan. Pemberdayaan masyarakat dalam merawat obyek-obyek bersejarah. Membentuk dan membina kelompok sadar wisata disetiap objek wisata yang memiliki potensi untuk dikembangkan.

\section{Terhadap Akomodasi yang tersedia}

Akomodasi merupakan salah satu pendukung kepariwisataan yang sangat penting selain fasilitas-fasilitas pendukung pariwisata lainnya. Ketersediaan pelayanan akomodasi di daerah kawasan wisata merupakan syarat mutlak karena berpengaruh terhadap perkembangan pariwisata. Pulau Penyengat sebagai salah satu daerah tujuan wisata di Provinsi Kepulauan Riau memiliki berbagai jenis wisata, seperti wisata sejarah, budaya dan religi telah menarik minat wisatawan mancanegara untuk datang berkunjung. Kedatangan wisatawan mancanegara tersebut karena adanya fasilitas penginapan (hotel, motel, wisma, maupun losmen), travel biro, dan tempat-tempat hiburan. Akomodasi mutlak harus tersedia untuk mendukung kepariwisataan di sebuah daerah yang memiliki objek wisata yang dapat diunggulkan sehingga wisatawan yang datang akan meningkat. Secara prinsipil komponen akomodasi di kota Tanjung Pinang sebagai daerah tujuan wisata sudah memadai. Namun secara kenyataannya di Pulau Penyengat akomodasi yang tersedia hanyalah rumah masyarakat setempat, sehingga kurangnya fasilitas akomodasi hotel maupun penginapan lainnya. Rata-rata wisatawan menjawab cukup baik yaitu 11 orang $36,7 \%$. Namun masih ada wisatawan yang menjawab tidak baik yaitu 7 orang $23,3 \%$. Alasan wisatawan menjawab tidak baik atas adalah dikarenakan minimnya akomodasi yang tersedia di Pulau Penyengat dan kurangnya fasilitas pendukung akomodasi di hotel maupun penginapan lainnya. Sehingga para wisatawan tidak memiliki kesempatan untuk berlama-lama menikmati wisata di Pulau Penyengat. Fasilitas pendukung akomodasi seperti restoran dan tempat hiburan tradisional masih minim sekali, hanya disaat event-event tertentu saja sedangkan kunjungan wisatawan dilakukan sepanjang tahun bagi wisatawan yang tidak mengetahui jadwal event tersebut berlangsung.

\section{Terhadap Transportasi Yang tersedia}

Ada beberapa faktor mendasar yang perlu ditingkatkan menurut wisatawan terhadap kondisi transportasi di kota Tanjung Pinang. Menurut penilaian wisatawan kondisi transportasi ke luar dan di dalam kota Tanjung Pinang sudah cukup memadai namun mesti ada program peningkatan di masa yang akan datang. Penambahan sarana angkutan kota menuju tempat dan objek wisata sangat diperlukan karena angkutan yang ada di kota Tanjung Pinang pada saat ini sangat terbatas. Rata-rata menjawab tidak baik yaitu 9 orang $30 \%$ alasan wisatawan menjawab demikian dikarenakan beberapa hal yaitu: Untuk mengunjungi Pulau Penyengat transportasi yang tersedia hanyalah menggunakan transportasi laut yaitu kapal (Pompong). Perjalanan laut ditempuh lebih kurang 15 menit dari kota Tanjung Pinang. Adapun Pelabuhan yang digunakan untuk berlabuh ke Pulau 
Penyengat ada 2 yang mana terletak pada jalan pelabuhan 1 dan Jln DT. Ibrahim (pelabuhan ke-2). Sedangkan saat ini pintu masuk ke kota Tanjung Pinang praktis hanya dapat ditempuh melalui transportasi laut sebagai jalur angkutan yang paling dominan. Untuk transportasi udara sudah dapat digunakan bandara Kijang hanya sebatas rute Tanjung Pinang - Jakarta, untuk rute yang lain masih di pertimbangkan oleh maskapai penerbangan yang ada. Penambahan angkutan udara diperlukan guna meningkatkan standar pelayanan wisata sehingga memudahkan wisatawan untuk mendatangi tempat dan objek wisata yang hendak dituju seperti Pulau penyengat. Transportasi yang digunakan untuk mengelilingi situs yang ada di Pulau Penyengat ada 3 yaitu, motor sewaan (Rp $25.000 / 1$ jam), ojek motor (Rp 25.000/1 jam), becak motor $(\operatorname{Rp} 25.000 / 1$ jam) dan sepeda sewaan (Rp.10.000/1 jam)

Terhadap Iklan dan Promosi tentang Pulau Penyengat yang dilakukan Dinas Kebudayaan dan Pariwisata kota Tanjung Pinang

Untuk memperkenalkan suatu daerah tujuan wisata maka sangat diperlukan adanya kegiatan promosi. Keadaan yang terlihat di Pulau Penyengat pada saat ini, kegiatan promosi tempat dan objek wisata gaungnya kurang terdengar oleh wisatawan. Kebanyakan wisatawan mendapatkan informasi tentang Pulau Penyengat dari wisatawan lainnya yang telah datang berkunjung. Iklan dan Promosi tentang Pulau Penyengat yang dilakukan Dinas Kebudayaan dan Pariwisata kota Tanjung Pinang rata-rata menjawab tidak baik yaitu 10 orang $33 \%$ alasan wisatawan menjawab demikian dikarenakan beberapa hal yaitu: Iklan dan promosi yang telah dilakukan oleh Dinas Kebudayaan dan Pariwisata Kota Tanjung Pinang Provinsi Kepulauan Riau sepertinya salah sasaran, hal ini ditunjukkan oleh jumlah wisatawan yang menjawab tidak baik sebanyak 10 orang. Para wisatawan merasa kesulitan untuk mendapatkan informasi tentang objek wisata yang dikunjungi karena tiadanya pemandu wisata professional di tempat dan objek wisata.

\section{PEMBAHASAN}

Secara Astronomi Pulau Penyengat terletak pada $\mathrm{O}^{0} 56^{\prime} \mathrm{LU}$ dan $104^{0} 29^{\prime} \mathrm{BT}$ dengan panjang $2 \mathrm{~km}$, lebar $1 \mathrm{~km}$. Pulau Penyengat ini sering disebut dengan istilah Pulau Maskawin karena pulau ini merupakan Maskawin Sultan Mahmudsyah untuk Engku Puteri Raja Hamidah. Pulau Penyengat dikenal dengan nama Pulau Penyengat Indra Sakti. Di pulau ini banyak binatang sejenis lebah yang dikenal dengan nama penyengat, lalu para pelaut yang singgah dipulau ini sekedar mangambil air untuk minum disengatnya. Pada tahun 1803 Pulau Penyengat dipergunakan sebagai tempat kedudukan kerajaan yang Dipertuan Muda Riau-Lingga.

Pulau Penyengat merupakan sebuah pulau kecil yang letaknya sekitar $6 \mathrm{~km}$ dari Kota Tanjung Pinang. Pulau Penyengat luasnya kurang lebih 2.500 meter x 750 meter. Jarak Pulau Penyengat juga tidak terlalu jauh dari Pulau Batam, sehingga menarik minat wisatawan untuk berlibur ke pulau ini. Untuk akses menuju pulau ini dapat di capai dengan memakai perahu bot atau dalam bahasa setempat lebih dikenal pompong. Waktu yang di butuhkan jika wisatawan menggunakan pompong hanya sekitar 15 menit dengan ongkos yang cukup terjangkau.

Pulau Penyengat juga merupakan salah satu obyek wisata andalan di Kepulauan Riau, salah satu objek yang kita lihat adalah masjid yang dibangun pada masa Engku Putri Raja Hamidah ini, beliau merupakan istri Sultan Mahmud Syah, penguasa Riau. Pada awalnya, Masjid Raya Pulau Penyengat ini hanya berlantai batu bata dengan menara yang tingginya kurang dari 6 meter. Lalu masjid ini diperbaiki dan diperbesar oleh Yang Dipertuan Muda Raja Abdul Rahman.

Masjid ini dibangun secara gotong royong oleh masyarakat hingga ke kawasan Riau Lingga untuk membantu bahan 
bangunan dan makanan. Dan warna tembok bangunan Masjid Raya Pulau Penyengat tersebut dibuat memakai kuning telur. Masjid Raya Pulau Penyengat ini ditetapkan sebagai masjid pertama yang memakai kubah pada atapnya. Masjid Raya Pulau Penyengat ini memiliki luas $54 \times 32$ meter, dengan luas bangunan $29 \times 19$ meter, ketebalan dindingnya mencapai $50 \mathrm{~cm}$, sehingga menjadikan Masjid Raya Pulau Penyengat ini sangat kokoh dan menjadi satu-satunya peninggalan Kerajaan Riau Lingga yang tersisa.

Masjid yang didominasi dengan warna kuning yang sangat mencolok telah menjadi bangunan yang langsung terlihat dari dermaga panjang dan Pelabuhan Sri Bintan Pura di Kota Tanjung Pinang. Masjid Raya Pulau Penyengat ini memiliki 13 belas kubah dan 4 menara masjid berujung runcing setinggi 19 meter. Jika jumlah kubah dan menara dijumlahkan, maka 17 adalah penunjuk bilangan rakaat shalat dalam satu hari. Di pintu masuk Masjid Raya Pulau Penyengat ini, terdapat Al Quran yang ditulis oleh Abdurrahman pada tahun $1867 \mathrm{M}$, dikisahkan Beliau ini adalah putra Riau yang belajar di Istambul Turki dan Al Quran tersebut ditulis olehnya ketika mengajar agama Islam di Pulau Penyengat, Kepulauan Riau. Masjid yang tercatat dalam sejarah sebagai merupakan satu-satunya peninggalan Kerajaan Riau-Lingga yang masih ada ini berukuran sekitar 54 x 32 meter. Ukuran bangunan induknya sekitar 29 x 19 meter.

Pembangunan masjid secara besarbesaran dilakukan ketika Raja Abdul Rahman memegang jabatan Yang Dipertuan Muda Riau-Lingga (1832-1844) menggantikan Raja Ja'far. Tak lama setelah memegang jabatan itu, pada 1 Syawal tahun $1284 \mathrm{H}(1832 \mathrm{M})$ atau 165 tahun yang lalu, setelah usai shalat Ied, ia menyeru masyarakat untuk bergotong royong membangun masjid. Dalam gotong royong itulah masyarakat membawa berbagai perbekalan. Termasuk telur karena berlimpah, banyak putih telur yang tidak habis dimakan. Dan oleh pekerja putih telur itu dijadikan campuran adukan. Menurut mereka dengan campuran putih telur bangunan akan lebih kokoh dan tahan lama. Dari situlah masyarakat sekitar juga menyebut Masjid Raya Pulau Penyengat ini dengan masjid putih telur.

Dalam buku Tuhfat al-Nafis (Sejarah Melayu) karya Raja Ali Haji, Masjid ini dibangun seiringan dengan dihadiahkannya pulau Penyengat kepada Engku Putri Hamidah oleh Sultan Mahmud. Saat itu Masjid masih terbuat dari kayu. Pada masa Raja Ja'afar, yang membangun Penyengat sebagai bandar modern, Masjid ini pernah diperlebar karena pertambahan penduduk. Dalam buku Masjid Pulau Penyengat yang disusun Hasan Junus menyebutkan, Masjid ini dibangun secara besar-besaran pada pemerintahan Yang Dipertuan Muda (YDM) Raja Abdul Rahman (1832-1844). Kini kawasan Masjid berukuran 54,4 x 32,2 meter, dengan bangunan induknya adalah 29,3 x 19,5 meter, disangga empat tiang. Lantai dibuat dari batu bata tanah liat.

Di halaman Masjid terdapat dua buah rumah sotoh (tempat pertemuan) yang diperuntukkan bagi musafir dan tempat musyawarah. Terdapat juga dua balai, tempat untuk menyediakan hidangan ketika kenduri atau untuk berbuka puasa yang disediakan pengurus Masjid setiap harinya. Masjid yang berlantai batu merah empat persegi, dengan dinding terbuat dari kayu Cengal (balanocarpus heimii) didatangkan dari Selangor.

Selain masjid ada juga makam rajaraja, yakni Raja Ja'afar dan kantor Raja Ali Marhum yang berada di tengah-tengah pulau Penyengat dan Komplek Makam Engku Putri Hamidah

\section{Istana Raja Ali Marhum Kantor}

Istana Kantor adalah Istana Raja Ali YDMR VIII (1844-1857) atau disebut dengan Marhum Kantor. Istana ini berada di tengah Pulau Penyengat $150 \mathrm{~m}$ sebelah barat daya Mesjid Raya Pulau Penyengat. Bangunan utamanya bertingkat dua, pada mulanya merupakan Kantor Raja Ali. Sekeliling areal bangunan dibatasi dengan tembok 3 buah pintu masuk dari arah barat, utara dan timur. 
Pintu gapura barat yang sekaligus berfungsi sebagai penjagaan dan pengintaian, pintu gerbang utara merupakan tempat kolam pemandian, pintu gerbang timur merupakan tempat pintu darurat. Di halaman bagian dalam tembok keliling masih terdapat bekas sisa-sisa lantai bangunan.

Komplek Makam Yang Dipertuan Muda (Raja) Riau VI Raja Ja'afar

Raja Ja'afar atau Yang Dipertuan Muda Riau VI adalah Raja Riau yang mengembangkan pertambangan timah di Singkep. Masa pemerintahannya berlangsung pada saat Belanda dan Inggris memperebutkan wilayah jajahan, beliau meninggal di Daik-Lingga dan kemudian dimakamkan di Pulau Peyengat. Raja Ja'afar memerintah pada tahun 1805 1832. Di dalam komplek makam ini terdapat pula Makam Raja Ali atau Yang Dipertuan Muda Riau VIII (1844 - 1857), Raja Ali adalah anak dari Raja Haji Fisabilillah. Makam kedua tokoh ini berdampingan, kedua makam ini berada didalam sebuah bangunan dengan atap berbentuk kubah. Pada bagian luar terdapat "kolah" atau tempat air untuk bersuci, kedua nisan makam raja ini berupa nisan berbentuk ganda.

\section{Komplek Makam Engku Putri Hamidah}

Di dalam komplek makam yang memiliki struktur atap bersusun dengan arsitektur yang indah ini terdapat beberapa makam pembesar Kerajaan Riau yang salah satunya adalah makam Engku Puteri. Engku Puteri yang memiliki nama lahir Raja Hamidah merupakan anak dari Raja Haji Yang Dipertuan Muda Riau ke IV. Perkawinannya dengan Sultan Mahmud mengantar Engku Puteri Raja Hamidah menjadi tokoh yang sangat penting dalam kerajaan Riau Johor pada awal abad ke-19. Kepandainyalah diamanahkan alat-alat pusaka (regalia) kerajaan. Tanpa alat-alat pusaka itu penobatan seorang Sultan menjadi tidak sah menurut adat setempat. Pulau Penyengat juga merupakan mas kawin dari Sultan Mahmud kepada Engku Puteri. Engku Puteri wafat pada tahun 1844. Selain makam Engku Puteri juga terdapat makam Raja Haji Abdullah Yang Dipertuan Muda Riau IX dan makam Raja Ali Haji sastrawan dari Kerajaan Riau Lingga dengan karyanya yang terkenal adalah Gurindam Dua Belas.

Banyaknya wisatawan yang berlibur untuk berkunjung di Kepulauan Riau juga sangat membanggakan bagi provinsi yang terletak di pulau Sumatera ini. Banyak tempat menarik dari obyek wisata Indonesia yang ada di provinsi Kepulauan Riau seperti wisata religi, budaya dan sejarah. Pulau Penyengat juga merupakan salah satu obyek wisata di Kepulauan Riau, salah satu objek yang bisa kita lihat adalah Mesjid Raya Pulau Penyengat. Adapun potensi yang di miliki berupa keunikan-keunikan pada Mesjid Raya Pulau Penyengat adalah sebagai berikut :

1. Salah satu mesjid yang menggunakan putih teloh sebagai bahan campuran pada pembangunannya.

2. Mesjid pertama yang menggunakan kubah pada atapnya di daerah Kepulauan Riau.

3. Masuknya ajaran agama islam pertama kali di Kepulauan Riau.

4. Mesjid yang tercatat dalam sejarah Indonesia sebagai salah satu peninggalan bersejarah kerajaan Riau-Lingga yang masih ada.

5. Mesjid Raya Pulau Penyngat terdapat 13 kubah dan 4 menara berujung runcing setinggi 19 meter, jika jumlah kubah dan menara menunjukkan bilangan rakaat sholat dalam 1 hari.

6. Didalam Mesjid Raya Pulau Penyengat terdapat buku Tuhfat al-Nafis yang di tulis oleh Raja Ali Haji sebagai pujangga kerajaan Riau-Lingga.

7. Di halaman Mesjid Raya Pulau Penyengat terdapat dua buah rumah sotoh (tempat pertemuan) yang di peruntukkan bagi musafir dan tempat munyawarah, dan ada lagi dua balai tempat untuk menyediakan hidangan ketika kenduri atau untuk berbuka puasa yang di sediakan pengurus Mesjid Raya Pulau Penyengat. 
294 Promosi Mesjid Raya Pulau Penyengat sebagai Daerah Tujuan Wisata di Tanjung Pinang Kepulauan Riau (Riono Gede Trisoko)

Pulau Penyengat tidak hanya menjadi objek wisata religi tetapi juga merupakan objek wisata sejarah. Mesjid Raya Pulau Penyengat saja memiliki keunikan tersendiri yaitu menggunakan putih telor sebagai bahan campuran pembangunan nya terbukti masik kuat hingga saat ini dan menjadi bukti sejarah. Pulau Penyengat sendiri sebenarnya adalah mas kawin yang di berikan Sultan Mahmud kepada Engku Putri Hamida, di saat itulah Pulau Penyengat berkembang dan menjadi Bandar modern yang disinggahi para pelaut dapat beribadah sekligus beristirahat.

\section{SIMPULAN}

Mesjid Raya Pulau Penyengat merupakan salah satu andalan dalam mendukung wisata religi dan wisata sejarah kota Tanjung Pinang mengingat banyaknya peninggalan situs sejarah di pulau ini yang bisa menjadi objek unggulan bagi wisatawan domestic dan wisatawan internasional. Dan ada pun upaya promosi yang di lakukan oleh Dinas Kebudayaan dan Pariwisata dalam meningkatkan jumlah kunjungan seperti : tersedianya pusat informasi pariwisata, diadakannya festival pulau penyengat, diadakan kerjasama dengan travel biro dan memperbanyak iklan tentang pulau penyengat. Dan keberadaan Dinas Kebudayaan dan Pariwisata saat ini dapat di katakan baik. Dengan berbagai promosi yang dilakukan oleh Dinas terkait sehingga kedepan dapat meningkatkan kunjungan.

\section{DAFTAR RUJUKAN}

Bryden, M John. 2003. Pariwisata Dalam Ekonomi. Kanisius. Yogyakarta

Kaelany H D. 2003, Pengetahuan Kepariwisatan, Alfabetha, Bandung.

Ma. Desky, 2003, Manajemen Perjalanan Wisata, Adicita, Yogyakarta

Oka A. Yoeti. 2006. Ilmu Pariwisata Sebuah Pengantar Sederhana. Jakarta. PT. Pradnya Paramita.

Oka A. Yoeti 2003. Pengantar Ilmu Pariwisata. Bandung, Angkasa
Oka. A. Yoeti. 2005, Pemasaran Pariwisata

Terpadu, Angkasa, Bandung.

Bahar. 2009. Pariwisata Dalam Ekonomi. Kanisius. Yogyakarta

Direktorat Jendral, 1997, Pariwisata Indonesia, Direktorat Jendral Pariwisata, Jakarta

Gamal Suwantoro, 1997, Dasar-Dasar Pariwisata, Andi Yogyakarta

Happy Marpurung, 2002, Gejala Pariwisata, Alfabetha Bandung

Himawan Kertajaya 2009, Manajemen Perjalanan Wisata, Adicitra Karya Nusa, Yogyakarta

Kaelany. 2007, Pengembangan Daya Tarik Wisata. Pustaka Sinar Harapan. Jakarta.

Kotler. Philip. 2000 Manajemen Pemasaran. Penerjemah Adi Zakaria Afif. 2002. Jakarta. Lembaga Penerbit FE UI.

Kotler. Philip dan Amstrong. 2001, Pemandu Wisata ( Tour Guiding ), Graha Ilmu, Jakarta

MA. Desky. 2001, Pengantar Bisnis Biro Perjalanan Wisata, Adicitra Karya Nusa, Yogyakarta

M. Kesrul.2003. Penyelenggaraan Operasi Perjalanan Wisata. PT. Grasindo

Moleong, Lexy.J, 2005, Metode Penelitian Kualitatif (Edisi Revisi),

Rosdakarya, Bandung.

Nyoman S. Pendit. 1996. Ilmu usaha Dan Perjalanan Wisata. Pradnya Paramitha. Jakarta. 2006, Ilmu Pariwisata, PT. Pradnya Paramita, Jakarta

RS. Damardjati. 2001, Istilah-Istilah Dunia Pariwisata, Pradnya Paramita, Jakarta

Salah Wahab, 1992, Pemasaran pariwisata, PT. Pradnya Paramita, Jakarta

Sri Wulandari. 2001. Pariwisata dan Pembangunan Ekonomi. Upada Sastra. Denpasar.

Stanton. 1996. Pengembangan Daya Tarik Wisata. Pustaka Sinar Harapan. Jakarta. 
Promosi Mesjid Raya Pulau Penyengat sebagai Daerah Tujuan Wisata di Tanjung Pinang Kepulauan

Sumadi Suryabrata. 1992. Metodologi Riau (Riono Gede Trisoko) Penelitian, Rajawali Pers, Jakarta.

Team Penyusun Materi. Metodologi Penelitian, Program Diploma III, IV, Sekolah Tinggi Pariwisata, Bandung.

Undang-undang Kepariwisataan Republik

Indonesia. Ilmu Pariwisata. 2009.

Jakarta 